\title{
TNF Inhibitor Therapy for Rheumatoid Arthritis
}

\section{Xixi Ma and Shengqian X $\mathbf{u}^{*}$}

Department of Rheumatology \& Immunology, the First Affiliated Hospital of Anhui Medical University, Hefei, 230022, China

\begin{abstract}
Immunotherapy has improved considerably the treatment outcomes in rheumatoid arthritis (RA). Tumor necrosis factor (TNF)- $\alpha$ antagonists have been widely used for the treatment of RA such as infliximab, etanercept, adalimumab and the recent two new TNF- $\alpha$ inhibitors - certolizumab pegol and golimumab. Infliximab, a chimeric monoclonal antibody, binds with high affinity and specificity to human TNF and cancels out its biologic activity. Etanercept is also monoclonal antibody, but it is a solute protein. Adalimumab is a recombinant human IgG monoclonal antibody specific for human TNF-a. Infliximab, when used in combination with methotrexate (MTX), provides significant, clinically relevant improvement in physical function and quality of life, inhibits the progressive joint damage, and sustains improvement in the signs and symptoms of patients with RA. Etanercept monotherapy is effective and safe for patients with RA. Combination therapy with etanercept and MTX reduces disease activity, decreases total joint score progression, slows the pace of joint destruction, and improves function more effectively than does either monotherapy. Adalimumab with or without MTX also relieves the signs and symptoms of RA. Certolizumab pegol and golimumab expand the therapeutic schedule for patients with RA. All the TNF- $\alpha$ inhibitors have similar efficacy in clinical treatment, but they have distinct clinical pharmacokinetic and pharmacodynamic properties that must be considered when selecting a drug for therapy. The common adverse events of these TNF- $\alpha$ antagonists include adverse reactions, infections, injection-site reaction and so on. And these adverse events are mostly mild or moderate and the incidence is low. Some patients show a lack of response to anti-TNF- $\alpha$ therapies, either due to the lack of drug efficacy or following the development of adverse events. These patients may discontinue the first drug and switch to a second anti-TNF- $\alpha$ agent. The shortage of clinical response to one agent may not predict deficiency of response to another. This review mainly addresses the latest development of these biological agents in the treatment of RA, including clinical efficacy, physical function, radiographic progression and adverse events.
\end{abstract}

Keywords: Rheumatoid arthritis; Immunotherapy; Biological agent

\section{Introduction}

Rheumatoid arthritis (RA) is a chronic inflammatory disease characterized by progressive joint destruction. As their joints deteriorating, patients suffer pain and loss of function, often accompany with decreasing quality of life and increasing mortality [1]. Depending on the severity of the disease at onset, the risk of disability can be as high as $30 \%$, and mortality can be increased by as much as $52 \%$, frequently as a result of infection or circulatory disease [2].

RA treatment aims to minimize disease activity thereby prevents or controls joint damage and diminishes the risk of other serious comorbidities such as heart disease and stroke. It is absolutely necessary that early intervention in patients with confirmed RA to preserve joint function [3-5].

Non-steroidal anti-inflammatory drugs (NSAIDs) and glucocorticoids are used to control pain and inflammatory process [6]. After defined the diagnosis of RA, patients are given disease-modifying antirheumatic drugs (DMARDs), which reduce signs and symptoms of the disease, and can inhibit in radiographic progression [6]. While many RA patients do respond to DMARDs, a large proportion of RA remained active despite such treatments. The approach of targeting cytokines has dramatically improved the success in the treatment of RA. Five TNF- $\alpha$ inhibitors are available, infliximab, etanercept, adalimumab [7-10], golimumab and certolizumab pegol, in the clinical application.

This paper focuses on how these agents have developed in the aspect of their effects on symptoms (evaluated by American College of Rheumatology [ACR] response criteria), structure (in the light of the erosion, joint-space narrowing, and Sharp scores), and physical function (based on standardized questionnaires such as the Health Assessment Questionnaire [HAQ]).

\section{Tumor necrosis factor- $\alpha$ antagonist}

TNF- $\alpha$ is an important cytokine that mediates inflammation in RA. Elevations of TNF- $\alpha$ level have been observed in synovial fluid and the synovium of patients with RA [11]. TNF- $\alpha$ plays a very central role in driving a inflammation and associated bone degradation [12]. Because it has an influence on various cell in synovial membrane, such as synoviocytes, macrophages, chondrocytes and osteoclasts, which can produce metalloproteinas, collagenase, stromelysin and so on, result in local inflammation and pannus formation, eventually lead to further erosion of cartilage and bone destruction. Introduction of TNF-a inhibitors revolutionize RA treatment options and bring about the development of further biologic DMARDs [13]. The effects of a TNF- $\alpha$ blockade are partially dependent on synovial TNF- $\alpha$ expression and in filtration by TNF- $\alpha$-producing inflammatory cells [14]. The progress of biotechnology contributes to the development of biological agents such as anti-TNF- $\alpha$ monoclonal antibodies as a strategy for the treatment of chronic inflammatory disease.

\section{Infliximab}

Infliximab is a recombinant IgG1 monoclonal antibody specific for TNF- $\alpha$, which hinders the cytokine from triggering the cellular TNF receptor complex [15]. Infliximab must be given by intravenous

*Corresponding author: Shengqian Xu, Department of Rheumatology \& Immunology, the First Affiliated Hospital of Anhui Medical University, Hefei, 230022, China, E-mail: xsqian-1112@163.com

Received January 20, 2012; Published July 28, 2012

Citation: Ma X, Xu S (2012) TNF Inhibitor Therapy for Rheumatoid Arthritis. 1 155. doi: $10.4172 /$ scientificreports. 155

Copyright: (c) $2012 \mathrm{Ma} \mathrm{X}$, et al. This is an open-access article distributed unde the terms of the Creative Commons Attribution License, which permits unrestricted use, distribution, and reproduction in any medium, provided the original author and source are credited. 
infusion and has a terminal half-life of 8 to 10 days. Hence it is administered every 4 to 8 weeks and the dosage lies between 3 to 5 (to 10) $\mathrm{mg} / \mathrm{kg}$.

The efficacy of infliximab with MTX has been demonstrated in several trials (Table1). Patients receiving combination therapy achieved obviously higher median improvements in ACR-N than those in the MTX plus placebo group [16-18]. In addition, the clinical efficacy is similar in different dosage of infliximab group [16-18]. In terms of radiographic image, the combination of infliximab and MTX prevented the radiographic progression and led to lasting clinical amelioration [16]. Infliximab treatment inhibited progression of joint damage even in patients take low of MTX in the RISING study [18]. Compared with the MTX-only-treated patients, both erosions and joint space narrowing obviously reduced from baseline in the infliximab plus MTX-treated patients except infliximab $3 \mathrm{mg} / \mathrm{kg}$ every 8 weeks. There were fewer newly eroded joints per patient in the infliximab plus MTX treatment groups than in the MTX-only group [17]. The studies by St Clair EW illustrated that HAQ scores accelerated more in the group conducted infliximab than in the group receiving MTX alone [16].

The most common adverse events found in clinical trials of infliximab included infusion reactions, infection. The therapy of infliximab might increase the risk of malignancies tumors and cardiovascular [19]. The incidence of serious infections, acute infusion reactions, and death was similar between patients treated with infliximab plus MTX and those adopted MTX only [17]. Among the serious infections, pneumonia, tuberculosis occurred more frequently in the infliximab-treated patients than in those treated with MTX alone $[16,19]$.

\section{Etanercept}

Etanercept is a genetically engineered protein consisting of two molecules of the extracellular domain of TNF receptor II (p75) and the Fc portion of IgG1 [20]. Owe to its half-life of approximately 3-5.5 days, etanercept is administered subcutaneously (s. c) either weekly (50mg) or twice a week (25mg) [21].

The superiority of the combination therapy of etanercept plus MTX over etanercept or MTX monotherapy in patients with RA has been demonstrated (Table 2) [22-24]. The 2-year data from the TEMPO study confirmed that apparently larger proportion of patients treated with combination therapy achieved the clinical response than that receiving either monotherapy [22]. Moreover, the combinationtreated patients had predominantly lower erosion change scores $(-0.67)$ than patients treated with etanercept alone (0.39) or MTX alone (3.25) [25]. Therefore, treatment with a combination of etanercept and MTX halted joint damage and patients achieved disease remission [25]. Sustained efficacy and decreased rate of radiographic progression gained in patients with early aggressive RA who use long-term treatment with etanercept [26]. Patients adopted combination therapy enhanced greatly in function status than in group of monotherapy [27]. Additionaly, etanercept $50 \mathrm{mg}$ once weekly is an optimal in most patients with RA. Increasing the dosage of etanercept from $50 \mathrm{mg}$ once a week to $50 \mathrm{mg}$ twice a week in suboptimal responders did not dramatically improve response rates [28]. There was no obvious improvement between etanercept as monotherapy at $50 \mathrm{mg}$ twice weekly and $25 \mathrm{mg}$ twice weekly with regard to the safety and efficacy [29].

Injection-site reactions and hypertension were more common with etanercept than with MTX or with combination therapy [22]. These events were mostly mild or moderate. Nausea and vomiting were more often concerned with MTX than with etanercept or combination therapy. No significant differences were seen among the groups in the incidence of serious adverse events (infectious and noninfectious) [22].

In summary, etanercept was benefit for patients with RA. But the combination of etanercept with MTX is superior to a montherapy with each drug. The combination regimen can reduce disease activity, slow radiographic progression and improve function. Furthermore, the treatment with etanercept plus MTX was well-tolerated and did not increase serious adverse events.

\section{Adalimumab}

Adalimumab is a monoclonal antibody of recombinant immunoglobulin (IgG1) containing only human sequences of peptides. It is an antagonist of TNF, which prevent the binding of TNF- $\alpha$ to its receptors [6]. It has a half-life of 10-20 days and can be used as monotherapy or in combination with several other DMARDs, preferably MTX [30,31]. The recommended dose of adalimumab is 25 mg s. c twice a week.

Treatment with adalimumab plus MTX was found to be statistically superior to placebo plus MTX according to the ACR20/50/70 response rates at week 26 (Table 3) [32]. If patients received

\begin{tabular}{|c|c|c|c|c|c|c|}
\hline First author & Groups & $\begin{array}{l}\text { Disease } \\
\text { duration }\end{array}$ & ACR20 & ACR50 & ACR70 & $\begin{array}{l}\text { vdH-S score } \\
\text { (Mean + SD) }\end{array}$ \\
\hline $\begin{array}{l}\text { St.Clair EW } \\
\text { et al. [16] }\end{array}$ & $\begin{array}{l}\text { IFX } 3 \mathrm{mg} / \mathrm{kg}+ \\
\text { MTX } \\
\text { IFX } 6 \mathrm{mg} / \mathrm{kg}+ \\
\text { MTX } \\
\text { Placebo + MTX }\end{array}$ & 54week & $\begin{array}{l}62.4 \\
66.2 \\
53.6\end{array}$ & $\begin{array}{l}45.6 \\
50.4 \\
32.1\end{array}$ & $\begin{array}{l}32.5 \\
37.2 \\
21.2\end{array}$ & $\begin{array}{l}0.4 \pm 5.8 \\
0.5 \pm 5.6 \\
3.7 \pm 9.6\end{array}$ \\
\hline $\begin{array}{l}\text { Maini RN et } \\
\text { al. [17] }\end{array}$ & $\begin{array}{l}\text { IFX 3mg/kg + } \\
\text { MTX } \\
\text { q8week } \\
\text { q4week } \\
\text { IFX10mg/kg + } \\
\text { MTX } \\
\text { q8week } \\
\text { q4week } \\
\text { Placebo + MTX }\end{array}$ & 102week & $\begin{array}{l}42 \\
40 \\
\\
48 \\
40 \\
16\end{array}$ & $\begin{array}{l}21 \\
30 \\
\\
36 \\
20 \\
6\end{array}$ & $\begin{array}{l}10 \\
21 \\
20 \\
10 \\
1\end{array}$ & $\begin{array}{l}1.02 \pm 7.13 \\
1.03 \pm 11.65 \\
1.14 \pm 4.92 \\
-0.42 \pm 6.10 \\
12.59 \pm \\
20.05\end{array}$ \\
\hline $\begin{array}{l}\text { Takeuchi T } \\
\text { et al. [18] }\end{array}$ & $\begin{array}{l}\text { IFX 3mg/kg + } \\
\text { MTX } \\
\text { IFX 6mg/kg + } \\
\text { MTX } \\
10 \mathrm{mg} / \mathrm{kg}+ \\
\text { MTX }\end{array}$ & 54week & $\begin{array}{l}75.8 \\
78.8 \\
82.7\end{array}$ & $\begin{array}{l}60.6 \\
58.7 \\
66.3\end{array}$ & $\begin{array}{l}37.4 \\
42.3 \\
43.3\end{array}$ & \\
\hline
\end{tabular}

IFX = infliximab; $\mathrm{MTX}=$ methotrexate $\mathrm{ACR}=$ American College of Rheumatology; $\mathrm{vdH}-\mathrm{S}=$ van der Heijde modification of the total Sharp score.

Table1: Comparison of clinical and radiographic response to infliximab plus MTX.

\begin{tabular}{|c|c|c|c|c|c|c|c|}
\hline First author & Groups & $\begin{array}{l}\text { Disease } \\
\text { Duration }\end{array}$ & ACR20 & ACR50 & ACR70 & $\begin{array}{l}\text { DAS28 } \\
<2.6(\%)\end{array}$ & $\begin{array}{c}\text { TTS } \\
\text { (mean) }\end{array}$ \\
\hline $\begin{array}{l}\text { Van der } \\
\text { Heijde D } \\
\text { et al. [22] }\end{array}$ & $\begin{array}{c}\mathrm{ETN}+\mathrm{MTX} \\
\mathrm{ETN} \\
\mathrm{MTX}\end{array}$ & 100 week & $\begin{array}{l}86 \\
75 \\
71 \\
\end{array}$ & $\begin{array}{l}71 \\
54 \\
42 \\
\end{array}$ & $\begin{array}{l}49 \\
27 \\
21\end{array}$ & $\begin{array}{l}42.4 \\
22.4 \\
18.9\end{array}$ & $\begin{array}{c}-0.56 \\
1.10 \\
3.34\end{array}$ \\
\hline $\begin{array}{c}\text { Kavanah A } \\
\text { et al. [23] }\end{array}$ & $\begin{array}{c}\text { ETN + MTX } \\
\text { ETN } \\
\text { MTX } \\
\text { ETN + MTX } \\
\text { ETN } \\
\text { MTX }\end{array}$ & 24 week & $\begin{array}{l}81,0 \\
70.8 \\
62.2\end{array}$ & $\begin{array}{l}83.8 \\
88.5 \\
50.0\end{array}$ & $\begin{array}{l}82.6 \\
66.7 \\
63.2\end{array}$ & & $\begin{array}{l}-1.35 \\
-0.19 \\
2.82\end{array}$ \\
\hline $\begin{array}{l}\text { Kameda H } \\
\text { et al. [24] }\end{array}$ & $\begin{array}{c}\text { ETN + MTX } \\
\text { ETN }\end{array}$ & 24 week & $\begin{array}{l}90.4 \\
63.8\end{array}$ & $\begin{array}{l}64.4 \\
47.8\end{array}$ & $\begin{array}{l}38.4 \\
26.1\end{array}$ & $\begin{array}{l}27.4 \\
10.1\end{array}$ & \\
\hline
\end{tabular}

ETN $=$ etanercept $;$ DAS = Disease Activity Score; DAS28 = DAS in 28 joints; TTS $=$ Total Sharp Scores

Table 2: Comparison of clinical and radiographic response to etanerceptplus MTX and monotherapy. 
adalimumab+MTX in early RA, they would achieve rapid clinical and functional improvements [32]. Adalimumab regimens decreased risk of radiographic disease progression [33]. In an open-label extension study of 5 years, the addition of adalimumab led to greater inhibition of structural damage compared with patients who continued with MTX monotherapy (Table 3) [34]. The PREMIESR study confirmed that treatment with adalimumab plus MTX is initiated early, it contribute to higher improvements in clinical, functional, and radiographic responses as compared with the treatment with MTX alone or adalimumab alone [35].

In addition, adlimumab plus MTX ameliorated physical function for patients with RA $[33,36]$.

Adalimumab had good tolerance generally. The research demonstrated that the rate of adverse events (both serious and nonserious) was similar in the adalimumab and placebo groups, although the proportion of patients reporting serious infections was higher in patients receiving adalimumab (3.8\%) than that in placebo $(0.5 \%)(\mathrm{P}<0.02)$, and was the highest in the patients adopted $40 \mathrm{mg}$ every other week [33]. The common adverse events were injection site reactions, serious infections such as military tuberculosis, cellulitis [35]. However, adalimumab were safe and well tolerated. These adverse events were not serious and severe side effects were relatively seldom.

\section{Golimumab}

Golimumab is a human anti-TNF- $\alpha$ monoclonal antibody that was generated and affinity matured in an in-vivo system [37]. Golimumab has a high affinity and specificity for human TNF- $\alpha$ and effectively neutralizes TNF- $\alpha$ bioactivity in vitro [38].

The efficacy of golimumab had been testified in several different groups (Table 4) $[37,39,40]$. The combination of golimumab and MTX was significantly better at improving the signs and symptoms of RA and physical funcion [37]. The differece weren't observed in the efficacy of the two golimumab dose group $(50 \mathrm{mg}$ and $100 \mathrm{mg}$ ) [37]. Though compared individually with the pacebo group, the golimumab in combination with MTX in patients with RA showed greater clinical response, the response rates did not displayed a clear dose-response pattern among the group of golimumab plus MTX (Table 4) [39].

In the multicenter, randomized, placebo-controlled GOFORWARD study, mean improvement from baseline in HAQ-DI was significantly greater for golimumab $50 \mathrm{mg}+\mathrm{MTX}$ and $100 \mathrm{mg}+\mathrm{MTX}$ versus placebo+MTX [41]. On the other hand, golimumab+MTX also elicited a significant better response than placeo+MTX in other efficacy parameters, including disease activity score (DAS28) response. And the combination of golimumab and MTX limit radiographic progression [42].

The safety of golimumab has been demonstrated in different trials. However, adverse events were reported in the process of treatment. The most frequent adverse events in the combined golimumab groups were nausea, headache, and injection sit reaction. Most events were mild or moderate in severity [43].

In general, golimumab, in combination with MTX, can alleviate the signs and symptoms of RA and improve physical function.

\section{Certolizumab pegol}

Certolizumab pegol is a humanized anti-TNF-aantibody with high affinity to TNF [44]. In managing patients with RA, the recommended dose of certolizumab pegol is $400 \mathrm{mg}$ (given as two subcutaneous injections of $200 \mathrm{mg}$ ) initially and at week 2 and 4, followed by $200 \mathrm{mg}$ every other week.

An international, multicentre, phase 3, randomized, double-blind, placebo-controlled study has assessed the efficacy of certolizumab pegol in MTX non-responders [45]. Compared to placebo treatment, certolizumab pegol plus MTX effectively reduced the signs and symptoms of RA, and inhibited progression of joint damage (Table 5) [45-46] .There were no obvious differences in clinical efficacy between the two certolizumab pegol dose groups [45]. Additionally, treatment with certolizumab pegol monotherapy also provided a rapid, meaningful and durable clinical response and and acceptable dafety profile (Table 5) [47]. Increasing the certolizumab pegol dose from 200 to $400 \mathrm{mg}$ did not give rise to an additional benefit in RA [48]. A research showed that the mean tender joint count ( -24.8 versus -24.6) or swollen joint count (-18.6 versus -18.7) was similar between the dose-escalation ( $200 \mathrm{mg}$ increased to $400 \mathrm{mg}$ every other week) and stable-dose subgroups ( $400 \mathrm{mg}$ every other week) [49]. The most common adverse reactions included tuberculosis, injection site pain and injection site reaction [46].

As shown above, certolizumab pegol monotherapy or the combination therapy with MTX as an effective treatment provides a rapid, meaningful and durable clinical response and an acceptable safety profile.

\section{Similarity and difference between anti-TNF agents}

As is well known, patients with RA have low quality of life. Clinical trials have shown that TNF- $\alpha$ blocking agents, such as etanercept,

\begin{tabular}{|c|c|c|c|c|c|c|c|}
\hline First author & Groups & $\begin{array}{l}\text { Disease } \\
\text { Duration }\end{array}$ & ACR20 & ACR50 & ACR70 & $\begin{array}{l}\text { DAS28 } \\
<2.6(\%)\end{array}$ & $\begin{array}{c}\text { TTS } \\
\text { (mean } \pm \\
\text { SD) }\end{array}$ \\
\hline $\begin{array}{l}\text { Kavanaugh } \\
\text { A et al. [32] }\end{array}$ & $\begin{array}{c}\mathrm{ADA}+\mathrm{MTX} \\
\mathrm{PBO}+ \\
\mathrm{MTX}\end{array}$ & Week 26 & $\begin{array}{l}70 \\
57\end{array}$ & $\begin{array}{l}52 \\
34\end{array}$ & $\begin{array}{l}35 \\
17\end{array}$ & $\begin{array}{l}34 \\
17\end{array}$ & \\
\hline $\begin{array}{c}\text { Keystone } \\
\text { EC et al. } \\
{[33]}\end{array}$ & $\begin{array}{c}\text { ADA40mg + } \\
\text { MTX } \\
\text { ADA20mg + } \\
\text { MTX } \\
\text { Placebo } \\
+ \text { MTX }\end{array}$ & Week 52 & $\begin{array}{l}58.9 \\
54.7 \\
24.0\end{array}$ & $\begin{array}{r}41.5 \\
37.7 \\
9.5\end{array}$ & $\begin{array}{c}23.2 \\
20.8 \\
4.5\end{array}$ & & $\begin{array}{l}0.1 \pm 4.8 \\
0.8 \pm 4.9 \\
2.7 \pm 6.8\end{array}$ \\
\hline
\end{tabular}

ADA = adalimumab

Table 3: Comparison of clinical and radiographic response to adalimumab plus MTX and monotherapy.

\begin{tabular}{|c|c|c|c|c|c|c|}
\hline $\begin{array}{l}\text { First } \\
\text { author }\end{array}$ & Group & $\begin{array}{l}\text { Disease } \\
\text { Duration }\end{array}$ & ACR20 & ACR50 & ACR70 & $\begin{array}{l}\text { DAS28 } \\
\text { (mean } \pm \\
\text { SD) }\end{array}$ \\
\hline $\begin{array}{l}\text { Keystone } \\
\text { EC et al. } \\
{[37]}\end{array}$ & $\begin{array}{l}\text { GOLI 50mg + MTX } \\
\text { GOLI 100mg + MTX } \\
\text { GOLI100mg + placebo } \\
\text { Placebo + MTX }\end{array}$ & Week 24 & $\begin{array}{l}59.6 \\
59.6 \\
35.3 \\
27.8\end{array}$ & $\begin{array}{l}37.1 \\
32.6 \\
19.5 \\
13.5\end{array}$ & $\begin{array}{l}20.2 \\
14.6 \\
11.3 \\
5.3\end{array}$ & \\
\hline $\begin{array}{l}\text { Kay J et } \\
\text { al. [39] }\end{array}$ & $\begin{array}{l}\text { GOLI + MIX } \\
50 \mathrm{mg} \text { (every } 4 \text { weeks) } \\
50 \mathrm{mg} \text { (every } 2 \text { weeks) } \\
100 \mathrm{mg} \text { (every4 weeks) } \\
100 \mathrm{mg} \text { (every2 weeks) } \\
\text { Placebo + MTX }\end{array}$ & Week 16 & $\begin{array}{l}60.0 \\
50.0 \\
55.9 \\
79.4 \\
37.1\end{array}$ & $\begin{array}{l}37.1 \\
23.5 \\
29.4 \\
32.4 \\
5.7 \\
\end{array}$ & $\begin{array}{l}8.6 \\
14.7 \\
17.6 \\
8.8 \\
0.0 \\
\end{array}$ & $\begin{array}{l}-1.9 \pm 1.3 \\
-1.4 \pm 1.3 \\
-1.9 \pm 1.5 \\
-1.9 \pm 1.1 \\
-0.9 \pm 1.0\end{array}$ \\
\hline $\begin{array}{l}\text { Weinblatt } \\
\text { ME et al. } \\
{[40]}\end{array}$ & $\begin{array}{l}\text { GOLI } 2 \mathrm{mg} / \mathrm{kg}+\mathrm{MTX} \\
\text { Placebo + MTX }\end{array}$ & Week16 & $\begin{array}{l}58.5^{*} \\
24.9\end{array}$ & $\begin{array}{l}34.9 \\
13.2\end{array}$ & $\begin{array}{l}17.7 \\
4.1\end{array}$ & $\begin{array}{l}-2.0 \pm 1.40 \\
-0.7 \pm 1.35\end{array}$ \\
\hline
\end{tabular}

GOLI = golimumab; *ACR20 responses was observed at week 14

Table 4: Comparison of clinical and radiographic response to golimumab plus MTX and monotherapy. 
infliximab, and adalimumab, relieve joint inflammations and slow radiographic progression of joint damage, and improve physical function in advanced RA [50-52]. The availability of newer agents, including certolizumab pegol and golimumab, has increased treatment options for patients with RA. Furthermore, anti-TNF- $\alpha$ agents are more efficacious in promoting the clinical signs and symptoms of RA than MTX alone. Anti-TNF- $\alpha$ agents plus MTX show sustained efficacy and remain more effective than ant-TNF- $\alpha$ monotherapy [53]. Compared with MTX and placebo, the ACR20,50,70 response rates for 1-year treatment with MTX plus any of the TNF inhibitors were $60 \%$ versus $25 \%, 40 \%$ versus $10 \%$, and $20 \%$ versus $5 \%$,respectivly [54].

However, they have distinct clinical pharmacokinetic and pharmacodynamic properties that must be considered when selecting a drug for therapy [55]. For example, there are obvious differences in the half-lives of the three agents (infliximab, etanercept, adalimumab), with etanercept having the shortest 3-5.5 days and adalimumab having the longest, 2 weeks [21]. Three kinds of biological agents also vary from each other in their dosing regimens [55]. The larger but less frequently administrated dose of infliximab may result in higher peak serum concentrations compared with the smaller but more commonly administrated doses of etanercept and adalimumab, giving rise to higher tissue concentrations [55]. Total efficacies of different biologics were very similar, which have been observated in most of studies and been accepted by many scholars [55]. Nevertheless a recent research indicated that there were significant difference in the efficacy of and adherence to therapy with adalimumab, etanercept, and infliximab [56]. Infliximab had the lowest treatment responsers, disease remission rates, and drug adherence rates. Adalimumab had the highest treatment responses and remission rates, while etanercept had the longest drug survival rates [56] (Table 6).

According to Singh's report [57], patients giving adalimab and infliximab were at remarkably bigger risk versus placebo. Indirect companies revealed that adalimumab was more tend to withdrawls rather than etanercept (OR 1.89, 95\% CI 1.18 to 3.04 ) and etanercept was less likely than infliximab (OR $0.37,95 \% \mathrm{CI} 0.19$ to 0.70 ). Additionally, there seem to be differences in the risk of tuberculosis (TB) among different biologics, and this might influence which patients went on to receive the biological agent. TB occurred more frequently in monoclonal antibodies-treated patients (that is, infliximab and adalimumab) than in those treated with soluble TNF receptor therapy (that is, entanercept ) $[58,59]$. Additionally, the rate of hospitalised infection for patients treated with other agents was less than for infliximab [60]. Among these biology, the incidence of serious infections was higher in certolizumab pegol group than others. Adalimumab, etanercept and golimumab were associated with a low incidence of treatment discontinuation because of adverse events, while the infliximab was not that [61]. Moreover, all biologic agents increased the risk of infections. So patients should be excluded tuberculosis and should receive pneumococcal, influenza, and hepatitis B vaccinations before they accept the therapy of biologic agents.

\section{Switching between different anti-TNF agents}

The patients may discontinue the first drug and switch to a second anti-TNF- $\alpha$ agent because of shortage of drug efficacy. How is the effect of the second biological agents? In a retrospective study [62], some patients $(n=20)$ switch from etanercept to infliximab and some patients $(n=73)$ treated infliximab with no prior TNF therapy. The C-reative protein, swollen and tender joint count, morning stiffness ameliorated in both groups, and there was no statistical difference in the degree of benefit between the groups [62]. On the other hand, infliximab may provide additional clinical profit for patients with an incomplete response to etanercept. Especially, patients taking infliximab revealed better amelioration in HAQ score than those receiving etanercept (Table 7) [63].

Another research concluded that patients switching to adalimumab had a good clinical response when the therapy of infliximab or etanercept was ineffective [64]. Patients who do not respond to a first anti-TNF drug may also subsequently gain improvements in HAQ score, if switch to a second agent [65]. Patients with RA may be successfully treated with another TNF- $\alpha$ agent, especially those withdrawing for inefficacy and adverse events [66].

The above result revealed that it was useful in switching among different biologic agents.

\section{Conclusion}

Biological agents make the treatment of RA into a new era, especially for patients with an insufficient response to DMARDs. Moreover, the strategies target IL-6, IL-1, T cell and B cell, which broaden our

\begin{tabular}{|c|c|c|c|c|c|c|c|}
\hline First author & Group & \begin{tabular}{|l|} 
Disease \\
Duration
\end{tabular} & ACR20 & ACR50 & ACR70 & $\begin{array}{l}\text { mTSS } \\
\text { (mean) }\end{array}$ & $\begin{array}{l}\text { DAS28 } \\
(\text { mean(SD)) }\end{array}$ \\
\hline $\begin{array}{l}\text { Smolen J } \\
\text { et al [45] }\end{array}$ & $\begin{array}{l}\text { CZP200mg + } \\
\text { MTX } \\
\text { CZP400mg + } \\
\text { MTX } \\
\text { Placebo + } \\
\text { MTX }\end{array}$ & Week24 & $\begin{array}{l}57.3 \\
57.6 \\
8.7\end{array}$ & $\begin{array}{l}32.5 \\
32.5 \\
33.1\end{array}$ & $\begin{array}{l}15.9 \\
10.6 \\
0.8\end{array}$ & $\begin{array}{l}0.2 \\
-0.4 \\
1.2\end{array}$ & $\begin{array}{l}-2.27(1.38) \\
-2.46(1.31) \\
-0.50(1.05)\end{array}$ \\
\hline $\begin{array}{l} \\
\text { Keystone } \\
\text { E et al [46] }\end{array}$ & $\begin{array}{l}\text { CZP200mg + } \\
\text { MTX } \\
\text { CZP400mg + } \\
\text { MTX } \\
\text { Placebo + } \\
\text { MTX }\end{array}$ & Week24 & $\begin{array}{l}58.8 \\
60.8 \\
13.6\end{array}$ & $\begin{array}{l}37.1 \\
39.9 \\
7.6\end{array}$ & $\begin{array}{l}21.4 \\
20.6 \\
3.0\end{array}$ & & $\begin{array}{l}-3.3 \pm 1.3 \\
-3.4 \pm 1.4 \\
-2.4 \pm 1.3\end{array}$ \\
\hline $\begin{array}{l}\text { Fleischm } \\
\text { ann R et al } \\
{[47]}\end{array}$ & $\begin{array}{l}\text { CZP 400mg } \\
\text { Placebo }\end{array}$ & Week 24 & $\begin{array}{l}45.4 \\
9.3\end{array}$ & $\begin{array}{l}22.7 \\
3.7\end{array}$ & $\begin{array}{l}5.5 \\
0.0\end{array}$ & & $\begin{array}{l}-1.5 \\
-0.6\end{array}$ \\
\hline
\end{tabular}

$\mathrm{CZP}=$ certolizumab pegol

Table 5: Comparison of clinical and radiographic response to golimumab plus MTX and monotherapy.

\begin{tabular}{|c|c|c|c|c|c|c|c|c|c|}
\hline & \multicolumn{2}{|c|}{ Aadlimumab } & \multicolumn{2}{|c|}{ Etanercept } & \multicolumn{3}{|c|}{ Infliximab } & \multicolumn{2}{|l|}{$P$} \\
\hline & $\begin{array}{l}6 \\
\text { months }\end{array}$ & $\left|\begin{array}{l}12 \\
\text { months }\end{array}\right|$ & 6 month & hs $\begin{array}{l}12 \\
\text { months }\end{array}$ & $6 \mathrm{~m}$ & months & $\begin{array}{l}12 \\
\text { months }\end{array}$ & $\begin{array}{l}6 \\
\text { months }\end{array}$ & $\begin{array}{l}12 \\
\text { months }\end{array}$ \\
\hline $\begin{array}{l}\text { EULAR } \\
\text { response } \\
\text { No. of } \\
\text { patients } \\
\text { Good } \\
\text { Moderate } \\
\text { No } \\
\text { response }\end{array}$ & $\begin{array}{l}536 \\
52 \\
33 \\
15\end{array}$ & $\begin{array}{l}444 \\
57 \\
30 \\
15\end{array}$ & $\begin{array}{l}414 \\
42 \\
39 \\
19\end{array}$ & $\begin{array}{l}377 \\
19 \\
99 \\
9\end{array}$ & $\begin{array}{l}889 \\
34 \\
38 \\
29\end{array}$ & $\begin{array}{l}690 \\
40 \\
39 \\
21\end{array}$ & & $\begin{array}{l}<0.0001 \\
<0.0001\end{array}$ & \\
\hline $\begin{array}{l}\text { DAS28 } \\
\text { remission } \\
\text { No. of } \\
\text { patients } \\
\text { Remission } \\
\text { LUNDEX } \\
\text { corrected }\end{array}$ & $\begin{array}{l}536 \\
32 \\
26\end{array}$ & $\begin{array}{l}444 \\
39 \\
27\end{array}$ & $\begin{array}{l}377 \\
33 \\
24\end{array}$ & $\begin{array}{l}889 \\
21 \\
17\end{array}$ & $\begin{array}{l}690 \\
27 \\
16\end{array}$ & $\begin{array}{l}690 \\
27 \\
16\end{array}$ & & $\begin{array}{l}<0.0001 \\
<0.0001 \\
<0.0001 \\
<0.0001\end{array}$ & \\
\hline $\begin{array}{l}\text { ACR } \\
\text { response } \\
\text { No.of } \\
\text { patients } \\
\text { ACR50 } \\
\text { ACR70 }\end{array}$ & $\begin{array}{l}519 \\
45 \\
24\end{array}$ & $\begin{array}{l}426 \\
53 \\
30\end{array}$ & $\begin{array}{l}346 \\
45 \\
27\end{array}$ & $\begin{array}{l}852 \\
31 \\
14\end{array}$ & $\begin{array}{l}852 \\
31 \\
14\end{array}$ & $\begin{array}{l}660 \\
38 \\
17\end{array}$ & & $\begin{array}{l}<0.0001 \\
<0.0001 \\
<0.0001 \\
<0.0001\end{array}$ & \\
\hline
\end{tabular}

EULAR = European League Against Rheumatism

Table 6: Clinical responses after 6 months and 12 months of treatment: values the percent. 


\begin{tabular}{|l|c|c|}
\hline Clinical end point & Infliximab & Etanercept \\
\hline ACR20 response,\% & 61.5 & 28.6 \\
ACR50 response,\% & 30.7 & 14.3 \\
DAS28 & & \\
Mean(SD) & $4.0(1.5)$ & $5.2(1.6)$ \\
\% change from baseline & $-30.8(28.6)$ & $-16.0(24.2)$ \\
Patients with DAS28 score<2.6, \% & 15.4 & 7.1 \\
Patients with HAQ decrease $>0.22, \%$ & 61.5 & 14.3 \\
Patients with HAQ decrease $>0.40, \%$ & 38.5 & 0.0 \\
\hline
\end{tabular}

28 patients with an inadequate response to etanercept were randomized $1: 1$ to discontinue etanercept and receive infliximab $3 \mathrm{mg} / \mathrm{kg}$ at weeks $0,2,6,14$ and 22, or to continue etanercept $25 \mathrm{mg}$ twice weekly (patients received background methotrexate). Efficacy results at week 16.

Table 7: Switching between different anti-TNF agents.

idea of the therapy on RA. Biological agents can quickly relieve clinical symptoms and delay the bone destruction. When the TNF-a inhibitors apply to clinical practice, the combinations with DMARDs are conducive to ease the symptoms and prevent the bone structural damage and elevate physical function. Besides, the conversion between different agents can reach the same function. Some drugs, such as etanercept, in combination with MTX were better than monotherapy in the long-term efficacy. A higher dosage of certain agents, etanercept, anakinra, rituximab, abatacept, appears to have a better clinical efficacy. Most adverse events of agents are infection-site reactions. Thought large side-effect can be cured by appropriate treatment, they still prevent the clinical remedy. As physicians, we should not only prescribe different treatment according to the patient's symptoms but also need to constantly explore the immune mechanism of RA, and develop new biological agents. In the future, immunotherapy will bring fundamental changes for the patients with RA.

\section{References}

1. Nanke Y, Kotake S, Akama H, Kamatani N (2002) Alkaline phosphatase in rheumatoid arthritis patients: possible contribution of bone-type ALP to the raised activities of ALP in rheumatoid arthritis patients. Clin Rheumatol 21 198-202.

2. Mikuls TR, Saag KG, Criswell LA, Merlino LA, Kaslow RA, et al. (2002) Mortality risk associated with rheumatoid arthritis in a prospective cohort of older women: results from the lowa Women's Health Study. Ann Rheum Dis 61: 994-999.

3. Kremer JM, Russell AS, Emery P, Abud-Mendoza C, Szechinski J, et al. (2011) Long-term safety, efficacy and inhibition of radiographic progression with abatacept treatment in patients with rheumatoid arthritis and an inadequate response to methotrexate: 3 -year results from the AIM trial. Ann Rheum Dis 70: $1826-1830$

4. Keystone E, Freundlich B, Schiff M, Li J, Hooper M (2009) Patients with moderate rheumatoid arthritis (RA) achieve better disease activity states with etanercept treatment than patients with severe RA. J Rheumatol 36: 522-531.

5. Baumgartner SW, Fleischmann RM, Moreland LW, Schiff MH, Markenson J, et al. (2004) Etanercept (Enbrel) in patients with rheumatoid arthritis with recent onset versus established disease: improvement in disability. J Rheumatol 31: 1532-1537.

6. Wiens A, Correr CJ, Venson R, Otuki MF, Pontarolo R (2010) A systematic review and meta-analysis of the efficacy and safety of adalimumab for treating rheumatoid arthritis. Rheumatol Int 30: 1063-1070.

7. Smolen JS, Han C, Bala M, Maini RN, Kalden JR, et al. (2005) Evidence of radiographic benefit of treatment with infliximab plus methotrexate in rheumatoid arthritis patients who had no clinical improvement: a detailed subanalysis of data from the anti-tumor necrosis factor trial in rheumatoid arthritis with concomitant therapy study. Arthritis Rheum 52: 1020-1030.

8. Gao GH, Li J, Xie HW, Lü Z (2010) Therapeutic effect of infliximab on moderate and severe active rheumatoid arthritis. Nan Fang Yi Ke Da Xue Xue Bao 30: 724-726.

9. Mathias SD, Colwell HH, Miller DP, Moreland LW, Buatti M, et al. (2000) Healthrelated quality of life and functional status of patients with rheumatoid arthritis randomly assigned to receive etanercept or placebo. Clin Ther 22: 128-139.
10. Breedveld FC, Weisman $\mathrm{MH}$, Kavanaugh AF, Cohen SB, Pavelka $\mathrm{K}$, et al (2006) The PREMIER study: A multicenter, randomized, double-blind clinical trial of combination therapy with adalimumab plus methotrexate versus methotrexate alone or adalimumab alone in patients with early, aggressive rheumatoid arthritis who had not had previous methotrexate treatment. Arthritis Rheum 54: 26-37.

11. Fütterer A, Mink K, Luz A, Kosco-Vilbois MH, Pfeffer K (1998) The lymphotoxin beta receptor controls organogenesis and affinity maturation in peripheral lymphoid tissues. Immunity 9: 59-70.

12. Visvanathan S, Rahman MU, Keystone E, Genovese M, Klareskog L, et al (2010) Association of serum markers with improvement in clinical response measures after treatment with golimumab in patients with active rheumatoid arthritis despite receiving methotrexate: results from the GO-FORWARD study. Arthritis Res Ther 12: 211.

13. Kleinert S, Tony HP, Krause A, Feuchtenberger M, Wassenberg S, et al (2011) Impact of patient and disease characteristics on therapeutic success during adalimumab treatment of patients with rheumatoid arthritis: data from a German noninterventional observational study. Rheumatol Int

14. Wijbrandts CA, Dijkgraaf MG, Kraan MC, Vinkenoog M, Smeets TJ, et al. (2008) The clinical response to infliximab in rheumatoid arthritis is in part dependent on pretreatment tumour necrosis factor alpha expression in the synovium. Ann Rheum Dis 67: 1139-1144.

15. Feldmann M, Elliott MJ, Woody JN, Maini RN (1997) Anti-tumor necrosis factoralpha therapy of rheumatoid arthritis. Adv Immunol 64: 283-350.

16. St Clair EW, van der Heijde DM, Smolen JS, Maini RN, Bathon JM, et al. (2004) Combination of infliximab and methotrexate therapy for early rheumatoid arthritis: a randomized, controlled trial. Arthritis Rheum 50: 3432-3443.

17. Maini RN, Breedveld FC, Kalden JR, Smolen JS, Furst D, et al. (2004) Sustained improvement over two years in physical function, structural damage, and signs and symptoms among patients with rheumatoid arthritis treated with infliximab and methotrexate. Arthritis Rheum 50: 1051-1065.

18. Takeuchi T, Miyasaka N, Inoue K, Abe T, Koike T; RISING study (2009) Impact of trough serum level on radiographic and clinical response to infliximab plus methotrexate in patients with rheumatoid arthritis: results from the RISING study. Mod Rheumatol 19: 478-487

19. Delabaye I, De Keyser F; REMITRACT study group (2010) 74-week follow-up of safety of infliximab in patients with refractory rheumatoid arthritis. Arthritis Res Ther 12: R121.

20. Moreland LW, Baumgartner SW, Schiff MH, Tindall EA, Fleischmann RM, et al. (1997) Treatment of rheumatoid arthritis with a recombinant human tumo necrosis factor receptor (p75)-Fc fusion protein. N Engl J Med 337: 141-147.

21. Saag KG, Teng GG, Patkar NM, Anuntiyo J, Finney C, et al. (2008) American College of Rheumatology 2008 recommendations for the use of nonbiologic and biologic disease-modifying antirheumatic drugs in rheumatoid arthritis. Arthritis Rheum 59: 762-784.

22. van der Heijde D, Klareskog $L$, Rodriguez-Valverde V, Codreanu $C$, et al. (2006) Comparison of etanercept and methotrexate, alone and combined, in the treatment of rheumatoid arthritis: two-year clinical and radiographic results from the TEMPO study, a double-blind, randomized trial. Arthritis Rheum 54 1063-1074.

23. Kavanaugh A, Klareskog L, van der Heijde D, Li J, Freundlich B, et al. (2008) Improvements in clinical response between 12 and 24 weeks in patients with rheumatoid arthritis on etanercept therapy with or without methotrexate. Ann Rheum Dis 67: 1444-1447.

24. Kameda H, Ueki Y, Saito K, Nagaoka S, Hidaka T, et al. (2010) Japan Biologica Agent Study Integrated Consortium. Etanercept (ETN) with methotrexate (MTX) is better than ETN monotherapy in patients with active rheumatoid arthritis despite MTX therapy: a randomized trial. Mod Rheumatol 20: 531-538.

25. van der Heijde D, Klareskog L, Landewé R, Bruyn GA, Cantagrel A, et al. (2007) Disease remission and sustained halting of radiographic progression with combination etanercept and methotrexate in patients with rheumatoid arthritis. Arthritis Rheum 56: 3928-3939.

26. Genovese MC, Bathon JM, Fleischmann RM, Moreland LW, Martin RW, et al (2005) Longterm safety, efficacy, and radiographic outcome with etanercept treatment in patients with early rheumatoid arthritis. J Rheumatol 32: 12321242.

27. van der Heijde D, Klareskog L, Singh A, Tornero J, Melo-Gomes J, et al. (2006) 
Patient reported outcomes in a trial of combination therapy with etanercept and methotrexate for rheumatoid arthritis: the TEMPO trial. Ann Rheum Dis 65: $328-334$

28. Weinblatt ME, Schiff MH, Ruderman EM, Bingham CO 3rd, Li J, et al. (2008) Efficacy and safety of etanercept $50 \mathrm{mg}$ twice a week in patients with rheumatoid arthritis who had a suboptimal response to etanercept $50 \mathrm{mg}$ once a week: results of a multicenter, randomized, double-blind, active drug-controlled study. Arthritis Rheum 58: 1921-1930.

29. Johnsen AK, Schiff MH, Mease PJ, Moreland LW, Maier AL, et al. (2006) Comparison of 2 doses of etanercept (50 vs $100 \mathrm{mg}$ ) in active rheumatoid arthritis: a randomized double blind study. J Rheumatol 33: 659-664.

30. van de Putte LB, Atkins C, Malaise M, Sany J, Russell AS, et al. (2004) Efficacy and safety of adalimumab as monotherapy in patients with rheumatoid arthritis for whom previous disease modifying antirheumatic drug treatment has failed. Ann Rheum Dis 63: 508-516.

31. Furst DE, Schiff MH, Fleischmann RM, Strand V, Birbara CA, et al. (2003) Adalimumab, a fully human anti tumor necrosis factor-alpha monoclonal antibody, and concomitant standard antirheumatic therapy for the treatment of rheumatoid arthritis: results of STAR (Safety Trial of Adalimumab in Rheumatoid Arthritis). J Rheumatol 30: 2563-2571.

32. Kavanaugh A, Fleischmann RM, Emery P, Kupper H, Redden L, et al. (2012) Clinical, functional and radiographic consequences of achieving stable low disease activity and remission with adalimumab plus methotrexate or methotrexate alone in early rheumatoid arthritis: 26-week results from the randomised, controlled OPTIMA study. Ann Rheum Dis.

33. Keystone EC, Kavanaugh AF, Sharp JT, Tannenbaum H, Hua Y, et al. (2004) Radiographic, clinical, and functional outcomes of treatment with adalimumab (a human anti-tumor necrosis factor monoclonal antibody) in patients with active rheumatoid arthritis receiving concomitant methotrexate therapy: a randomized, placebo-controlled, 52-week trial. Arthritis Rheum 50: 1400-1411.

34. Keystone EC, Kavanaugh A, Weinblatt ME, Patra K, Pangan AL (2011) Clinica consequences of delayed addition of adalimumab to methotrexate therapy over 5 years in patients with rheumatoid arthritis. J Rheumatol 38: 855-862.

35. Takeuchi T, Tanaka Y, Kaneko Y, Tanaka E, Hirata S, et al. (2011) Effectiveness and safety of adalimumab in Japanese patients with rheumatoid arthritis:retrospective analyses of data collected during the first year of adalimumab treatment in routine clinical practice (HARMONY study). Mod Rheumatol 22: 327-338.

36. Strand V, Rentz AM, Cifaldi MA, Chen N, Roy S, et al. (2012) Health-related quality of life outcomes of adalimumab for patients with early rheumatoid arthritis: results from a randomized multicenter study. J Rheumatol 39: 63-72.

37. Keystone EC, Genovese MC, Klareskog L, Hsia EC, Hall ST, et al. (2009) Golimumab, a human antibody to tumour necrosis factor \{alpha\} given by monthly subcutaneous injections, in active rheumatoid arthritis despite methotrexate therapy: the GO-FORWARD Study. Ann Rheum Dis 68: 789-796.

38. Shealy D, Cai A, Staquet K, Baker A, Lacy ER, et al. (2010) Characterization of golimumab, a human monoclonal antibody specific for human tumor necrosis factor alpha. MAbs 2

39. Kay J, Matteson EL, Dasgupta B, Nash P, Durez P, et al. (2008) Golimumab in patients with active rheumatoid arthritis despite treatment with methotrexate: a randomized, double-blind, placebo-controlled, dose-ranging study. Arthritis Rheum 58: 964-975.

40. Weinblatt ME, Bingham CO 3rd, Mendelsohn AM, Kim L, Mack M, et al. (2012) Intravenous golimumab is effective in patients with active rheumatoid arthritis despite methotrexate therapy with responses as early as week 2: results of the phase 3, randomised, multicentre, double-blind, placebo-controlled GOFURTHER trial. Ann Rheum Dis.

41. Genovese MC, Han C, Keystone EC, Hsia EC, Buchanan J, et al. (2012) Effect of Golimumab on Patient-reported Outcomes in Rheumatoid Arthritis: Results from the GO-FORWARD Study. J Rheumatol 39: 1185-1191.

42. Tanaka Y, Harigai M, Takeuchi T, Yamanaka H, Ishiguro N, et al. (2012) Golimumab in combination with methotrexate in Japanese patients with active rheumatoid arthritis: results of the GO-FORTH study. Ann Rheum Dis 71: 817824

43. Emery P, Fleischmann RM, Moreland LW, Hsia EC, Strusberg I, et al. (2009) Golimumab, a human anti-tumor necrosis factor alpha monoclonal antibody, injected subcutaneously every four weeks in methotrexate-naive patients with active rheumatoid arthritis: twenty-four-week results of a phase III, multicenter randomized, double-blind, placebo-controlled study of golimumab before methotrexate as first-line therapy for early-onset rheumatoid arthritis. Arthritis Rheum 60: 2272-2283.

44. Nesbitt A, Fossati G, Bergin M, Stephens P, Stephens S, et al. (2007) Mechanism of action of certolizumab pegol (CDP870): in vitro comparison with other anti-tumor necrosis factor alpha agents. Inflamm Bowel Dis 13: 13231332.

45. Smolen J, Landewé RB, Mease P, Brzezicki J, Mason D, et al. (2009) Efficacy and safety of certolizumab pegol plus methotrexate in active rheumatoid arthritis: the RAPID 2 study. A randomised controlled trial. Ann Rheum Dis 68: 797-804.

46. Keystone E, Heijde D, Mason D Jr, Landewé R, Vollenhoven RV, et al. (2008) Certolizumab pegol plus methotrexate is significantly more effective than placebo plus methotrexate in active rheumatoid arthritis: findings of a fifty-twoweek, phase III, multicenter, randomized, double-blind, placebo-controlled, parallel-group study. Arthritis Rheum 58: 3319-3329.

47. Fleischmann R, Vencovsky J, van Vollenhoven RF, Borenstein D, Box J, et al. (2009) Efficacy and safety of certolizumab pegol monotherapy every 4 weeks in patients with rheumatoid arthritis failing previous disease-modifying antirheumatic therapy: the FAST4WARD study. Ann Rheum Dis. 68: 805-811.

48. Keystone EC, Combe B, Smolen J, Strand V, Goel N, et al. (2012) Sustained efficacy of certolizumab pegol added to methotrexate in the treatment of rheumatoid arthritis: 2-year results from the RAPID 1 trial. Rheumatology (Oxford).

49. Curtis JR, Chen L, Luijtens K, Navarro-Millan I, Goel N, et al. (2011) Dose escalation of certolizumab pegol from $200 \mathrm{mg}$ to $400 \mathrm{mg}$ every other week provides no additional efficacy in rheumatoid arthritis: an analysis of individual patient-level data. Arthritis Rheum 63: 2203-2208.

50. Kekow J, Moots RJ, Emery P, Durez P, Koenig A, et al. (2010) Patientreported outcomes improve with etanercept plus methotrexate in active early rheumatoid arthritis and the improvement is strongly associated with remission the COMET trial. Ann Rheum Dis 69: 222-225.

51. Weinblatt ME, Kremer JM, Bankhurst AD, Bulpitt KJ, Fleischmann RM, et al (1999) A trial of etanercept, a recombinant tumor necrosis factor receptor:Fc fusion protein, in patients with rheumatoid arthritis receiving methotrexate. $\mathrm{N}$ Engl J Med 340: 253-259.

52. Haraoui B, Cividino A, Stewart J, Guérette B, Keystone EC (2011) Safety and effectiveness of adalimumab in a clinical setting that reflects Canadian standard of care for the treatment of rheumatoid arthritis (RA): results from the CanACT study. BMC Musculoskelet Disord 12: 261.

53. Aaltonen KJ, Virkki LM, Malmivaara A, Konttinen YT, Nordström DC, et al. (2012) Systematic review and meta-analysis of the efficacy and safety of existing TNF blocking agents in treatment of rheumatoid arthritis. PLoS One 7: e30275.

54. Caporali R, Pallavicini FB, Filippini M, Gorla R, Marchesoni A, et al. (2009) Treatment of rheumatoid arthritis with anti-TNF-alpha agents: a reappraisal. Autoimmun Rev 8: 274-280.

55. Hyrich KL, Lunt M, Watson KD, Symmons DP, Silman AJ (2007) British Society for Rheumatology Biologics Register. Outcomes after switching from one antitumor necrosis factor alpha agent to a second anti-tumor necrosis factor alpha agent in patients with rheumatoid arthritis: results from a large UK national cohort study. Arthritis Rheum 56:13-20.

56. Hetland ML, Christensen IJ, Tarp U, Dreyer L, Hansen A, et al. (2010) Direct comparison of treatment responses, remission rates, and drug adherence in patients with rheumatoid arthritis treated with adalimumab, etanercept, or infliximab: results from eight years of surveillance of clinical practice in the nationwide Danish DANBIO registry. Arthritis Rheum 62: 22-32.

57. Singh JA, Christensen R, Wells GA, Suarez-Almazor ME, Buchbinder R, et al (2010) Biologics for rheumatoid arthritis: an overview of Cochrane reviews. Sao Paulo Med J 128:309-310.

58. Fonseca JE, Canhão $H$, Silva C, Miguel C, Mediavilla MJ, et al. (2006) Tuberculosis in rheumatic patients treated with tumour necrosis factor alpha antagonists: the Portuguese experience. Acta Reumatol Port 31: 247-253.

59. Nam JL, Winthrop KL, van Vollenhoven RF, Pavelka K, Valesini G, et al. (2010) Current evidence for the management of rheumatoid arthritis with biologica disease-modifying antirheumatic drugs: a systematic literature review informing 
the EULAR recommendations for the management of RA. Ann Rheum Dis 69: 976-986

60. Curtis JR, Xie F, Chen L, Baddley JW, Beukelman T, et al. (2011) The comparative risk of serious infections among rheumatoid arthritis patients starting or switching biological agents. Ann Rheum Dis 70: 1401-1406.

61. Singh JA, Wells GA, Christensen R, Tanjong Ghogomu E, Maxwell L, et al. (2011) Adverse effects of biologics: a network meta-analysis and Cochrane overview. Cochrane Database Syst Rev CD008794.

62. Hansen KE, Hildebrand JP, Genovese MC, Cush JJ, Patel S, et al. (2004) The efficacy of switching from etanercept to infliximab in patients with rheumatoid arthritis. J Rheumatol 31: 1098-1102.

63. Furst DE, Gaylis N, Bray V, Olech E, Yocum D, et al. (2007) Open-label, pilot protocol of patients with rheumatoid arthritis who switch to infliximab after an incomplete response to etanercept: the opposite study. Ann Rheum Dis 66 893-899.

64. Wick MC, Ernestam S, Lindblad S, Bratt J, Klareskog L, et al. (2005) Adalimumab (Humira) restores clinical response in patients with secondary loss of efficacy from infliximab (Remicade) or etanercept (Enbrel): results from the STURE registry at Karolinska University Hospital. Scand J Rheumatol 34: 353-358.

65. Hyrich KL, Lunt M, Dixon WG, Watson KD, Symmons DP; BSR Biologics Register (2008) Effects of switching between anti-TNF therapies on HAQ response in patients who do not respond to their first anti-TNF drug Rheumatology (Oxford) 47: 1000-1005.

66. Scrivo R, Conti F, Spinelli FR, Truglia S, Magrini L, et al. (2009) Switching between TNFalpha antagonists in rheumatoid arthritis:personal experience and review of the literature. Reumatismo 61: 107-117. 